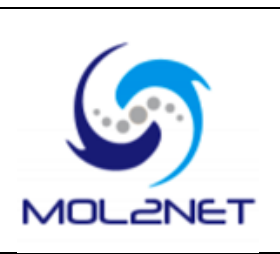

\title{
Salicola sp. strain SBJ9: a novel extremely halophilic bacterium with an interesting protease activity
}

\author{
Lobna Daoud $^{1,2, *}$, Adel Hadj Brahim ${ }^{1}$, Houda Hmani ${ }^{1}$, Asmahen Akremi ${ }^{1}$, Mouna Jlidi ${ }^{1}$, Manel \\ Ben Ali ${ }^{1,2}$, Samir Bejar ${ }^{1}$, Naser Aliye Feto ${ }^{3}$ and Mamdouh Ben Ali ${ }^{1,2}$
}

1 Laboratory of Microbial Biotechnology and Engineering Enzymes (LBMIE), Center of Biotechnology of Sfax (CBS), University of Sfax, Road of Sidi Mansour km 6, PO Box 1177 Sfax 3018, Tunisia; E-Mails: lobna.daoudm@gmail.com; adelhadjibrahim@gmail.com; houda_enis@yahoo.fr; asmahen.akremi@gmail.com; jlidimanno@yahoo.fr; manel.benali@gmail.com; samir.bejar@cbs.rnrt.tn; mamdouh.benali@cbs.rnrt.tn.

2 Astrum Biotech, Business incubator, Center of Biotechnology of Sfax (CBS), University of Sfax, Road of Sidi Mansour km 6, PO Box 1177 Sfax 3018, Tunisia; E-Mails: lobna.daoudm@gmail.com; manel.benali@gmail.com; mamdouh.benali@cbs.rnrt.tn.

3 OMICS Research Group \& Facility: Department of Biotechnology, Faculty of Applied \& Computer Sciences, Vanderbijlpark Campus, Private Bag, X021 - Vanderbijlpark - 1911 - Andries Potgieter Blvd - South Africa; E-Mail: naserf@vut.a.za.

* Correspondence addressed to Lobna Daoud; E-Mail: lobna.daoudm@gmail.com; Tel.: +21627658 016; Fax: +21674875818.

Received: / Accepted: / Published:

\begin{abstract}
:
A number of newly isolated halophilic microorganisms were screened for protease production. A bacterium designated as strain SBJ9 showed an important enzyme production at high salt concentrations and was then retained. The 16S DNA identification put this strain in the genus of Salicola with two reference species only. Protease production was higher at salinities ranging from 150 to $200 \mathrm{~g} / \mathrm{l}(3.2 \mathrm{M}) \mathrm{NaCl}$, when monitored at $35^{\circ} \mathrm{C}$ and $\mathrm{pH} 7$. The protease activity was optimal at $2.5 \mathrm{M} \mathrm{NaCl}, 40^{\circ} \mathrm{C}$ and $\mathrm{pH} 8$, with high stability at wide ranges of salinity (1-5 M $\mathrm{NaCl})$, temperatures $\left(20-70{ }^{\circ} \mathrm{C}\right)$ and $\mathrm{pH}$ values (5-11). It was slightly improved by $5 \mathrm{mM} \mathrm{CaCl} 2$ and totally inhibited by PMSF which indicated the dominance of serine proteases. Besides, it was perfectly stable in the presence of many detergent additives and organic solvents at high concentrations. These important features make Salicola sp. strain SBJ9 protease activity a good candidate for many industrial applications such as detergency and organic synthesis.
\end{abstract}

Keywords: extremely halophilic; Salicola sp.; protease; halo-thermostable; application.

\section{Introduction}

For many decades and even, proteases have been the first commercially available enzymes in the global enzyme market. In Fact, they are used in many industrial sectors as alternatives to chemicals to ameliorate the efficiency and the cost effectiveness [1]. As example, they are widely used in detergent, food and leather 
industries [2-5]. Practically, proteases used in detergent formulations are facing many technical constraints that reduce their stability such as $\mathrm{pH}$, ionic strength, salinity and the presence of surfactants. We noticed also the decrease of protease stability in liquid household detergents due to their high salt content. Thus, there are increasing studies on screening for new proteases that are active and stable under these harsh conditions.

In this context, we have focused on halophilic microorganisms (halophiles) which are known

\section{Results and Discussion}

Over a hundred of halophilic and halotolerant microorganisms were screened from various saline and hypersaline biotopes. Strain SBJ9, isolated from the Salt lake Bou Djemal in Sfax (Tunisia), showed the most important protease production on agar plates containing $200 \mathrm{~g} / \mathrm{l}$ $\mathrm{NaCl}(3.42 \mathrm{M})$ and was then retained. The $16 \mathrm{~S}$ rDNA identification put the isolate in the genus Salicola which contain only two species ( $S$. salis and $S$. marasensis). The study of the effect of salt for the production of enzymes with high activity and stability at wide ranges of salinity and in law water content media [6]. For that, we have isolated over a hundred of halophilic microorganisms and we have screened them for extracellular proteases production. A bacterium showing an important protease production at higher salinities, strain SBJ9, was selected for its identification and the further study of its protease activity.

on SBJ9 growth and protease production revealed that it is an extremely halophilic bacterium growing and producing protease activity optimally at $150-200 \mathrm{~g} / \mathrm{l} \mathrm{NaCl}$.

The biochemical characterization of Salicola sp. SBJ9 protease activity showed an optimal activity at $2.5 \mathrm{M} \mathrm{NaCl}, \mathrm{pH} 8$ and $40{ }^{\circ} \mathrm{C}$ with high stability at wide ranges of salinity $(1.5-5 \mathrm{M}$ $\mathrm{NaCl}), \mathrm{pH}(6-10)$ and temperature $\left(25-65{ }^{\circ} \mathrm{C}\right)$ (Figure 1).
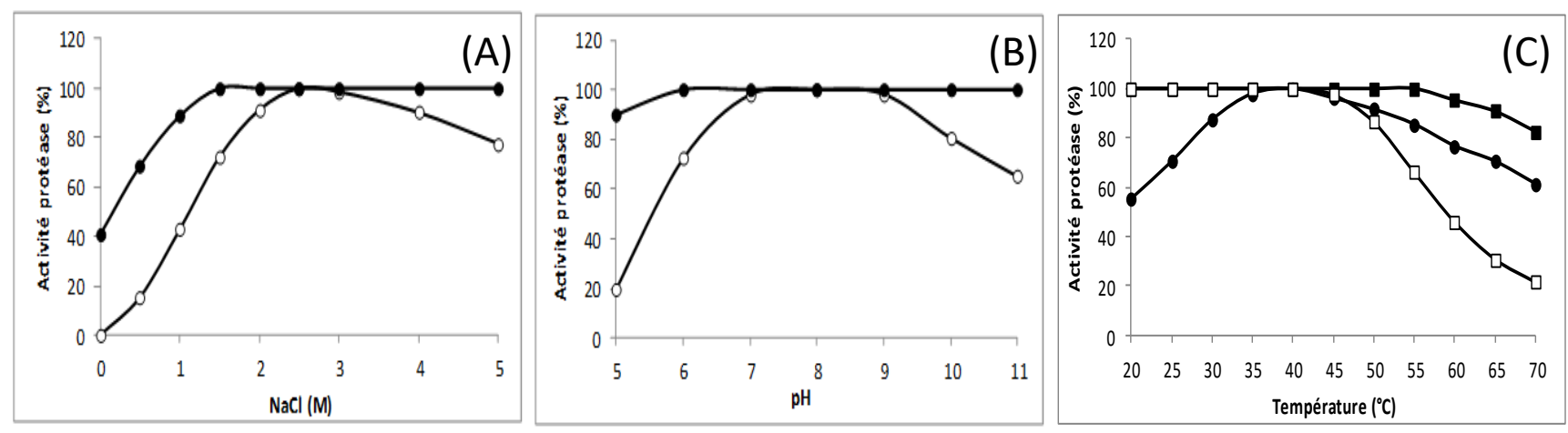

Figure 1. Effect of $\mathrm{NaCl}$ concentration (A), $\mathrm{pH}(\mathrm{B})$ and temperature $(\mathrm{C})$ on protease activity and stability from Salicola sp. SBJ9.

The effect of various chemical reagents on SBJ9 protease activity was also studied. Table 1 showed the effect of different metal ions and protease inhibitors on the enzymatic activity. It revealed a slight amelioration by $\mathrm{Ca}^{2+}$ ions and a total inhibition by $\mathrm{Co}^{2+}, \mathrm{Fe}^{2+}$ and PMSF which indicated that most of proteases exhibiting this activity are serine proteases. In addition, the protease activity was very stable in the presence of several organic solvents at $50 \%(\mathrm{v} / \mathrm{v})$ and detergent additives. As shown in Table 2, it is unaffected by acetonitrile and DMSO and presented more than $71.5 \%$ of residual activity with ethanol, isopropanol and butanol. Besides, it is perfectly stable in the presence of SDS (1\%), CTAB (25 mM), Triton X-100 (10\%), Tween 20, 40 and $80(10 \%)$ and $\mathrm{Na}_{2} \mathrm{CO}_{3}(100 \mathrm{mM})$, exceeding $77.9 \%$ of residual activity. Then, Salicola sp. SBJ9 protease activity is considered as a good candidate for detergent industry and organic biosynthesis. 
Table 2. effect of metal ions and protease inhibitors on protease activity from Salicola sp. SBJ9

\begin{tabular}{|lc|}
\hline Chemical agent & Protease activity (\%) \\
\hline None & 100 \\
Metallic ions (5 mM) & \\
$\mathrm{Cu}^{2+}$ & 85.5 \\
$\mathrm{Mn}^{2+}$ & 54.4 \\
$\mathrm{Mg}^{2+}$ & 100 \\
$\mathrm{Ba}^{2+}$ & 110.3 \\
$\mathrm{Zn}^{2+}$ & 52.7 \\
$\mathrm{Ca}^{2+}$ & 150.6 \\
$\mathrm{Co}^{2+}$ & 24.2 \\
$\mathrm{Fe}^{2+}$ & 12.6 \\
Protease inhibitors (5 mM if not indicated) \\
Pepstatin A $(10 \mu \mathrm{g} / \mathrm{ml})$ & 100 \\
$\mathrm{NEM}$ & 96.2 \\
$\mathrm{TPCK}$ & 94.5 \\
EDTA & 86.2 \\
Iodoacetamide & 57.8 \\
PMSF & 2
\end{tabular}

\section{Materials and Methods}

The screening of new halophilic microorganisms was monitored from various saline and hypersaline biotopes, on agar plates containing increasing concentrations of $\mathrm{NaCl}$ $(50,100,150$ and $200 \mathrm{~g} / \mathrm{l} \mathrm{NaCl})$. Protease production was detected by the presence of halo of degradation around the clone, in medium supplemented with $20 \%$ of skimmed milk. Molecular identification of the isolate SBJ9 was performed by the amplification of the $16 \mathrm{~S}$ rDNA gene, using the universal primers S73 (5'AGAGTTTGATCCTGGCTCAG) and S74 (5'AAGGAGGTGATCCAGCC) as direct and reverse primers, respectively. The PCR product $(\sim 1.5 \mathrm{~Kb})$ was purified, cloned in the pGEM-T Easy vector (Promega, USA) and sequenced in both directions.

Protease activity was assayed by the method of Kembhavi et al. [7] using Hammerstein casein (Merck, Germany) as substrate. One unit (U) of protease activity was defined as the amount of enzyme which liberated $1 \mu \mathrm{g}$ of tyrosine per minute under the experimental conditions. Protease activity represents the means of, at least, two determinations performed in duplicate. The difference between values did not exceed $5 \%$. The effect of $\mathrm{NaCl}$ concentration, $\mathrm{pH}$ and
Table 1. effect of organic solvents and detergent additives on protease activity from Salicola $\mathrm{sp.} \mathrm{SBJ9}$

\begin{tabular}{|lc|}
\hline Chemical reagent & Protease activity (\%) \\
\hline None & 100 \\
Detergent additives & \\
$\mathrm{H}_{2} \mathrm{O}_{2}(1 \%(\mathrm{v} / \mathrm{v}))$ & 60.4 \\
$\mathrm{SDS}(1 \%(\mathrm{w} / \mathrm{v}))$ & 92.4 \\
$\mathrm{CTAB}(25 \mathrm{mM})$ & 80.6 \\
Tween $20(10 \%(\mathrm{v} / \mathrm{v}))$ & 77.9 \\
Tween $40(10 \%(\mathrm{v} / \mathrm{v}))$ & 92.5 \\
Tween $80(10 \%(\mathrm{v} / \mathrm{v}))$ & 98.8 \\
Triton $\mathrm{X}-100(10 \%(\mathrm{v} / \mathrm{v}))$ & 90.7 \\
Na ${ }_{2} \mathrm{CO}$ & $(100 \mathrm{mM})$ \\
Organic solvents $(\mathbf{5 0} \%)$ & 100 \\
Methanol & \\
Ethanol & 66 \\
Isopropanol & 71.5 \\
Butanol & 80.6 \\
Acetonitrile & 89.4 \\
DMSO & 100 \\
\hline
\end{tabular}

temperature on protease activity and stability was studied by incubating the crude enzyme at 0 to 5 $\mathrm{M} \mathrm{NaCl}, 5$ to 11 and 20 to $70{ }^{\circ} \mathrm{C}$, respectively, and measuring relative and residual activities at standard assay conditions.

The effect of the different organic solvents and detergent additives on protease stability was examined by incubating the crude enzyme with each solvent at $50 \%(\mathrm{v} / \mathrm{v})$ and each additive at the appropriate concentration, indicated in table 2 , for $1 \mathrm{~h}$ at $30^{\circ} \mathrm{C}$, under kind shaking. Residual activities were carried under standard assay conditions. Enzyme activity without any additive was taken as control (100 $\%)$.

\section{Conclusions}

As a conclusion, Salicola sp. SBJ9 is an extremely halophilic bacterium producing an interesting protease activity which is distinguished by a good activity at high salt concentrations, neutral to alkaline $\mathrm{pH}$ values and room temperatures, conditions that are very required by many industrial applications. Besides, it is halo-alkalo-stable, thermo-solvent stable and compatible with different detergent chemicals. These important properties make strain SBJ9 protease activity as an effective candidate for many industrial and 
biotechnological applications at harsh conditions such as detergent industry, organic biosynthesis and bioremediation of saline environments. This report is the first one presenting a biochemical characterization of a protease activity from a Salicola sp. strain. Besides, SBJ9 Protease activity was about $170 \mathrm{U} / \mathrm{ml}$ which is much higher than the sole reported uncharacterized protease from Salicola sp. IC10 which is 0.1 $\mathrm{U} / \mathrm{ml}$ [8]. Due to the importance of the protease activity from Salicola sp. SBJ9, and probably of its other hydrolytic enzymes, the genome of this bacterium was sequenced in our laboratory, for the first time, and the corresponding genes were isolated to be then expressed.

\section{Acknowledgments}

This work was funded by the Tunisian Ministry of Higher Education and Scientific Research and Technology (contract program LMBEE-CBS, grant no. LR15CBS06).

\section{Conflicts of Interest}

The authors declare no conflict of interest.

\section{References and Notes}

1. Daoud, L.; Jlidi, M.; Hmani, H.; Hadj Brahim, A., El Arbi, M., Ben Ali, M. Characterization of thermo-solvent stable protease from Halobacillus sp. CJ4 isolated from Chott Eldjerid hypersaline lake in Tunisia. Journal of Basic Microbiology 2017, 57, 104- 113.

2. Kumar, D.; Savitri; Thakur, N.; Verma, R.; Bhalla, T.C. Microbial Proteases and Application as Laundry Detergent Additive. Research Journal of Microbiology 2008, 3, 661-672.

3. Lye, Y.C.; Gaik, T.T.; Amin, I. Chapter 15: Application of Proteases for the Production of Bioactive Peptides. In Enzymes in Food Biotechnology, e-book DOI https://doi.org/10.1016/C2016-0-04555-2; Mohammed Kuddus, Eds.; Elsevier, 2019; pp. 247261.

4. Choudhary, R.B., Jana, A.K., Jha M.K. Microbial proteases application in leather industry. Indian Journal of Chemical Technology 2004, 11, 659-671.

5. Kirk, O.; Borchert, T.V.; Fuglsang, C.C. Industrial enzyme applications. Current Opinion in Biotechnology 2002, 13:3, 45- 51.

6. Daoud, L.; Hmani, H.; Ben Ali, M.; Jlidi, M.; Ben Ali, M. An Original Halo-Alkaline Protease from Bacillus halodurans Strain US193: Biochemical Characterization and Potential Use as Bio-Additive in Detergents. Journal of Polymers and the Environment 2018, 26, 23-32.

7. Kembhavi, A.A.; Buttle, D.J.; Knight, C.G.; Barret, A.J. The two cycteine endopeptidases of legume seeds: purification and characterization by use of specific fluorometric assays. Archives of Biochemistry and Biophysics 1993, 303, 208 -213.

8. Moreno, M.L.; García, M.T.; Ventosa, A.; Mellado, E. Characterization of Salicola sp. IC10, a lipase- and protease producing extreme halophile. FEMS Microbiology Ecology 2009, 68, 59-71. 